\title{
Hydrochemistry and trophic state change in a large reservoir in the Brazilian northeast region under intense drought conditions
}

\author{
Janaína A. SANTOS, ${ }^{1}$ Rozane V. MARINS, ${ }^{1}$ José E. AGUIAR,,${ }^{1}$ Guillermo CHALAR,${ }^{2}$ Francisco A.T.F. SILVA, ${ }^{3}$ \\ Luiz D. LACERDA ${ }^{1 *}$
}

${ }^{1}$ Instituto de Ciências do Mar, Universidade Federal do Ceará, Av. Abolição 3207, Meireles 60165 081, Fortaleza, CE, Brasil; ${ }^{2}$ Facultad de Ciencias, Universidad de la Republica, Iguá 4225 Esq. Mataojo, C.P. 11400, Monevideo, Uruguay; ${ }^{3}$ Institutos Nacional de Pesquisas Espaciais - INPE, 61 760-000, Eusébio, CE, Brazil

*Corresponding author: ldrude@fortalnet.com.br

\begin{abstract}
The study shows changes on physical and chemical water parameters and of trophic state in a large reservoir in the Brazilian semiarid region following decreasing reservoir volume due to rainfall shortage during four consecutive years. The monitoring period, between November 2011 and May 2014, assessed approximately 50\% water volume reduction and 10 meters'decrease of reservoir water level that degraded water quality. Decrease in reservoir volume, strong evaporation and the permanent influence of anthropogenic activities, favored the concentration of salts and accumulation of nutrients and of increasing $\mathrm{pH}$. Thermal stratification of the water column occurred when volume was maximum and lead to a significant reduction in dissolved oxygen in the hypolimnion ( 0.07 to $2.62 \mathrm{mg} \mathrm{L^{-1 }}$ ). Diminishing volume resulted in mixing of the hypolimnion nutrient-rich and oxygen-poor waters in the entre water column and changed the initial oligotrophic condition to eutrophic. However, the temporal scale of the response of the reservoir's trophic state differs in the different areas of the reservoir. Whereas deeper areas accumulating nutrients from aquaculture and agriculture progressively became mesotrophic and eventually eutrophic; shallower regions far from direct anthropogenic influences, changed their trophic sate much later, but rapidly turned into super-eutrophic conditions, probably due to more intense sediment resuspension and water mixing. Trophic State Index followed nutrient increase during most of the period. However, it also responded to an increase in chlorophyll a concentrations when the reservoir achieved its minimum volume, in particular in the shallower areas. The results suggest that this type of reservoir systems are vulnerable to eutrophication during extended drought periods and that a better assessment of the maximum support capacity for reservoir activities, particularly aquaculture, must be re-assessed taking into consideration worst case scenarios forecasted by global climate change.
\end{abstract}

Key words: Reservoir; semiarid; trophic state index; eutrophication.

Received: January 2016. Accepted: August 2016.

\section{INTRODUCTION}

Reservoirs in semiarid regions, including those in Northeastern Brazil, witness unpredictable periods of rainfall when they receive extremely low watershed water inflow, exhibit high evaporation rates and a longer water residence time. These processes are the primary cause of water quality decrease due to increasing concentrations of dissolved salts (Freire et al., 2009). This scenario results in nutrient accumulation and concentration, leading to increasing algal density and the frequency of cyanobacteria blooms, thus rendering these systems much more vulnerable to eutrophication. The recent development of intensive fish cage aquaculture in many reservoirs in the Brazilian semiarid may contribute to a further deterioration of water quality, in particular during drought periods (Oliveira et al., 2015).

The trophic state of reservoirs in semiarid regions may vary according to reservoir volume (Braga et al., 2015), precipitation (Chaves et al., 2013), inputs of external loads of nutrients from surrounding soils (Lopes et al., 2014; Santos et al., 2014) and internal processes such as aquaculture (Bezerra et al., 2014). However, how these drivers interact to affect the trophic state of reservoirs are still poorly understood. Between 2011 and 2014, the northeastern semiarid region of Brazil witnessed a prolonged period of drought, resulting in a drastic reduction of the storage volume of artificial reservoirs. For example, the Castanhão reservoir, the largest multiuse reservoir in the region registered a drop from $88 \%$ to $27 \%$ of its storage capacity, rendering a unique opportunity to improve our understanding the relationship between volume and trophic state and the influence of anthropogenic pressures. The understanding of the reservoir's response during this period is of high significance since several externalities act to enhance the negative consequences of it. This longer period of abnormal low rainfall years may become more frequent and unpredictable due to climate change (PBMC, 2013), with direct impacts on the level of reservoirs, inputs of nutrients from diffuse sources and its eutrophication (Moss et al., 2011; Dawadi and Ahmad, 
2013; Umaña, 2014). On the other hand, water demand is increasing due to rapid regional development of irrigated agriculture and urbanization in recent years, in particular irrigate agriculture (Lacerda et al., 2008). Additionally, with the financial subsidies from the federal government to expand intensive fish-cage aquaculture to promote income and food safety for the region, the activity expanded by $20 \%$ per year, increasing environmental pressures within the reservoir proper (Oliveira et al., 2015). Therefore, sustainable use of the reservoirs services needs better modelling capability and scenarios construction in order to subsidize stockholder and decision makers. In this context, the present study aimed to spatially and temporally analyze and discuss the main physical and chemical water parameters of the Castanhão reservoir during a four-year period. Thereby contributing to the characterization of its trophic state in response to extended drought by applying the Trophic State Index approach to a comprehensive interpretation of the trophic variation in the reservoir.

\section{METHODS}

\section{Study area}

The study took place in the Castanhão reservoir (Latitude $5.50^{\circ} \mathrm{S}$; Longitude $38.47^{\circ} \mathrm{W}$ ) in the Middle
Jaguaribe River watershed, which is located entirely within the semiarid region in the State of Ceará, NE Brazil (Fig. 1). The semiarid climate of Northeastern Brazil features peculiarities resulting from the behavior of its regulating weather systems marked by irregularities in rainfall across time and space, with annual rainfall means commonly ranging from 400 to $1000 \mathrm{~mm}$ and average of $756.5 \mathrm{~mm}$ during the past 80 years (FUNCEME, 2014). Rainfall occurs from January to June and is scarce from July to December. During the study period, the monthly precipitation varied from 0-181 $\mathrm{mm}$. The years 2012, 2013 e 2014 were drier, with a mean annual rainfall of $302.3,656.5$ and $571.1 \mathrm{~mm}$, respectively, significantly below the historical annual average. This extended drought period relates to a strong El Nino event.

The Castanhão reservoir flooded completely for the first time in 2004. The total storage capacity of the reservoir is 6.7 billion $\mathrm{m}^{3}$, and the normal operating capacity is 4.45 billion $\mathrm{m}^{3}$. The reservoir covers a flooded area of $325 \mathrm{~km}^{2}$ and is $48 \mathrm{~km}$ in length, with a depth exceeding $50 \mathrm{~m}$ in some areas (DNOCS, 2014). The categories of the World Commission on Dams (2000) classify the Castanhão as a large reservoir. The reservoir is a multiple use lake with major function as water storage for human and agriculture uses. It harbors the largest fish aquaculture facility in the state and is also use for recreational objec-

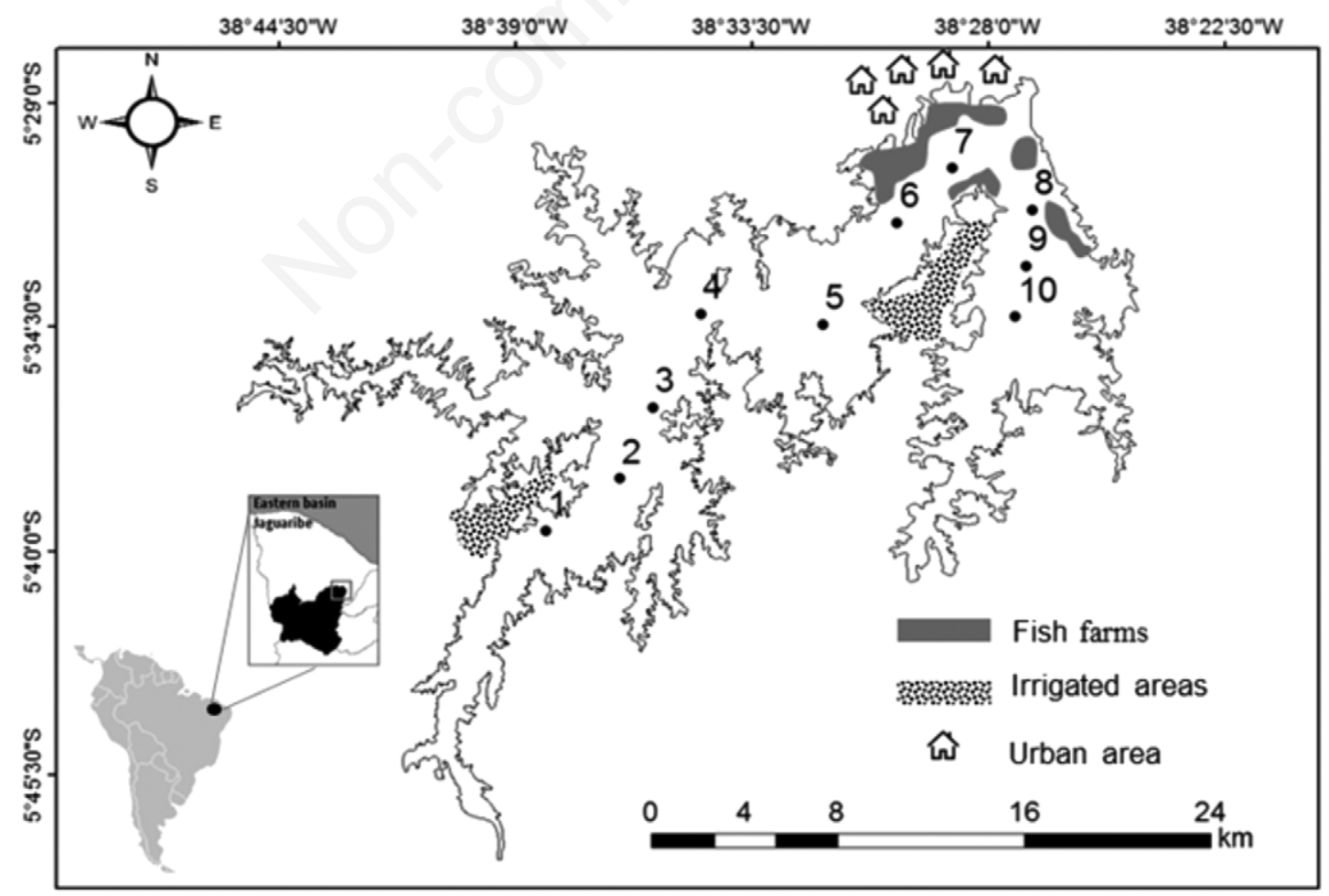

Fig. 1. Study area and location of sampling stations in the Castanhão reservoir, NE Brazil. 
tives, but not for energy production. The reservoir basin receives anthropogenic inputs of nutrients from different sources. Avelino (2015) developed a DPSIR analysis of the Castanhão reservoir and estimated, using established emission factors for these activities (Lacerda et al., 2008; Paula Filho et al., 2015) the total load of N and P from these sources. Annual direct emissions to the lake are mostly from fish farming, with an average annual production during the study period of about 18,000 tons of Nile Tilapia, and reached $519 \mathrm{t}$ of $\mathrm{N}$ and $163 \mathrm{t}$ of $\mathrm{P}$ ). In a recent study, Molisani et al. (2015) calculated 12 tons of $\mathrm{N}$ being emitted per 6-month production cycle from a fish farm in the Castanhão reservoir that produces about $448 t$ of fish annually. Extrapolating this figure for the total average production in the entire reservoir one reaches about 964 tons of $\mathrm{N}$. Those authors, however, did not indicate how emission factors were calculated and this number is probably an overestimation, but it is consistent with the annual emission of $\mathrm{N}$ estimated by Avelino (2015). Irrigated agriculture farms, covering 1254 ha and producing nearly 2 million tons mostly of fruit crops, are located around the lake, due to low-cost water availability. Runoff from these farms enters directly to the water body, totaling $198 \mathrm{t}$ and $149 \mathrm{t}$ of $\mathrm{N}$ and $\mathrm{P}$, respectively. Outside the reservoir margins, agriculture is restricted to subsidence farming and contributes little to the total nutrient emissions to the reservoir. Urban wastes and waste waters from local villages, totaling about 7400 inhabitants, are partially treated. Sewage collection reaches about $70 \%$ of the total effluent in urban areas, whereas nearly $90 \%$ of solid wastes are adequately disposed (IBGE, 2010). Rural areas have no wastewater or sewage collection or treatment and no solid waste disposal systems (IPECE, 2011). However, population is sparse, reaching about 3200 inhabitants. As a result, annual emissions of $\mathrm{N}$ and $\mathrm{P}$ are relatively small, reaching $271 \mathrm{t}$ of $\mathrm{N}$ and $73 \mathrm{t}$ of $\mathrm{P}$. Husbandry, mostly extensive cattle, although with a higher relative emission of about $1100 \mathrm{t}$ for both nutrients, is located in the upper reaches of the basin and hardly reaches the reservoir, mostly due to semiarid conditions hampering an effective transport from soil runoff (COGERH, 2011; Avelino, 2015). In summary, fish farming is the largest direct source of anthropogenic derived $\mathrm{N}$ and $\mathrm{P}$ to the reservoir and contributes with about $52.5 \%$ and $42.3 \%$ of the total anthropogenic direct emissions of $\mathrm{N}$ and $\mathrm{P}$, respectively.

Fig. 2 shows fluctuations in the volume of water stored in the reservoir during the studied period. These water level fluctuations are determined primarily by the dam system operation. However, during the sampling period, there was a drastic reduction in the stored volume due to the prolonged absence of rain in the reservoir's basin, resulting in a volume decrease from about $85 \%$ of its total water storage capacity in November, 2011 to about $35 \%$ of its total volume in May, 2014.

\section{Sampling}

Sampling campaigns occurred in November 2011, March and August 2012, January and August 2013 and May 2014, covering 10 stations located throughout the reservoir (Fig. 1). The sampling dates were chosen according to the annual rainfall distribution. Campaigns in November, March and January, occurred in rainy seasons; whereas August and May in dry seasons. In this way 3 rain and 3 dry periods were covered.

In the first two campaigns, only four and six stations respectively were sampled due to logistical problems. Previous to water collection, physical and chemical variables were measured in situ in surface waters $(0.5$ to $1.0 \mathrm{~m}$ depth) as follows: dissolved oxygen (YSI 556 probe, YSI Inc., Yellow Springs; water temperature, turbidity and electrical conductivity (Compact-CTD model AST D687; JFE Advantech Co., Ltd., Nishinomiya); pH (Portable 826 pH-meter; Metrohm AG, Herisau); and transparency with a Secchi disk. In addition, CTD and dissolved oxygen depth profiles in each station described thermal structure of the water column in all campaigns.

Water samples collected from the subsurface $(1.0 \mathrm{~m})$ in Van Dorn bottles were analyzed for inorganic nutrients after filtering in the field lab through 47-mm-diameter AP40 glass fiber filters. Samples were immediately frozen for transport and later analysis. Unfiltered samples were used to determine the total phosphorus and total nitrogen concentrations. Variables were quantified in triplicate, with the final detection performed by visible spectrum spectrophotometry, according to: ammonia nitrogen (Koroleff, 1970), nitrate (Braga et al., 2015), nitrite (Bendschneider and Robinson, 1952), total nitrogen and total phosphorus (Valderrama, 1981) and soluble reactive phosphorus (Murphy and Rilley, 1962).

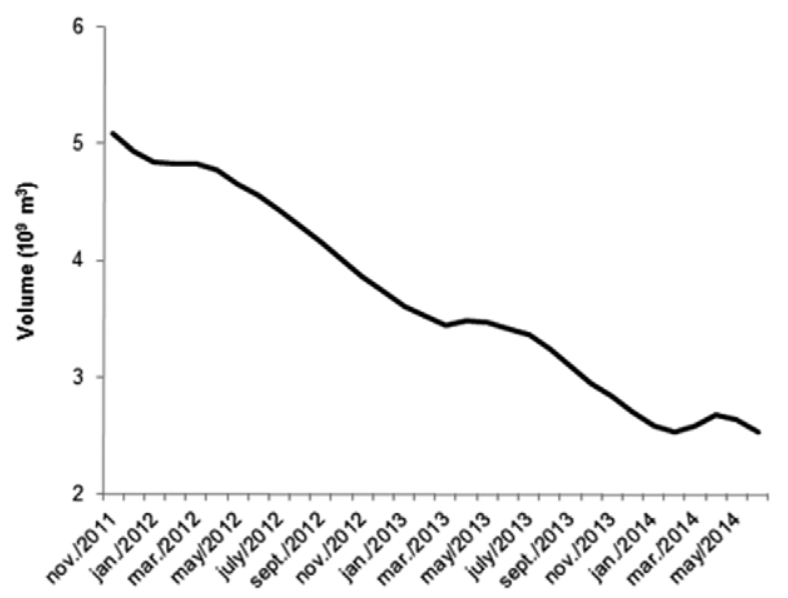

Fig. 2. Fluctuation of the water volume of the Castanhão reservoir, NE Brazil between 2011 and 2014 (DNOCS, 2014). 
To quantify chlorophyll a concentrations, the samples were filtered immediately after sampling in a field lab through 47-mm-diameter AP40 glass fiber filters. Filters were stored frozen and transported to the main laboratory were quantification was obtained in a spectrophotometer according to the ISO 10260 (1992) protocol.

The trophic state of the reservoir was estimated using the trophic index $\left(\mathrm{TSI}_{\mathrm{tsr}}\right)$ developed by Cunha et al. (2013). The index comprised the following equations that accounted for the concentrations of chlorophyll $a$ (Chla; $\mu \mathrm{g} \mathrm{L}^{-1}$ ) and total phosphorus (TP; $\mu \mathrm{g} \mathrm{L}^{-1}$ ):

TSI $(\text { Chl } a)_{\mathrm{tsr}}=10\left[6-\left(\frac{-0,2512 \ln \mathrm{Chl} a+0,842257}{\ln 2}\right)\right]($ eq. 1$)$

TSI $(\mathrm{TP})_{\mathrm{tsr}}=10\left[6-\left(\frac{-0,27637 \ln \mathrm{TP}+1,329766}{\ln 2}\right)\right] \quad$ (eq. 2$)$

$\mathrm{TSI}_{\mathrm{tsr}}=\frac{\mathrm{TSI}(\mathrm{TP})_{\mathrm{tsr}}+\mathrm{TSI}(\mathrm{Chla})_{\mathrm{tsr}}}{2}$

The defined limits for the trophic state classes were as follows: ultraoligotrophic: $\mathrm{TSI}_{\mathrm{tsr}} \leq 51.1$; oligotrophic: TSI $_{\mathrm{tsr}} \geq 51.2$ - 53.1; mesotrophic: $\mathrm{TSI}_{\mathrm{tsr}} \geq 53.2$ - 55.7; eutrophic: $\mathrm{TSI}_{\mathrm{tsr}} \geq 55.8-58.1$; supereutrophic: $\mathrm{TSI}_{\mathrm{tsr}} \geq 58.2$ - 59.0 and hypereutrophic: $\operatorname{TSI}_{\mathrm{tsr}} \geq 59.1$.

Principal Component Analysis (PCA), described the relationships between limnological variables and a cluster analysis to evaluate the longitudinal patterns in the reservoir and explore the similarities among sampling stations and define groups of associated ones. The analyses were performed using the STATISTICA 8.0 software package (StatSoft, Inc., Tulsa), assuming a significance level of $\alpha=0.05$. For the cluster analysis, the data matrix was normalized in $\mathrm{Z}$ and Ward's clustering method was used in combination with the Euclidean squared distances. The mean values of each parameter were subjected to means testing at a significance level of $\mathrm{P} \leq 0.05$.

\section{RESULTS}

Tab. 1 shows mean, minimum and maximum values of the limnological parameters monitored in the reservoir during the sampling period and considering all sampling stations, whereas Supplementary Tab. 1 shows all individual results. Even considering that samples were collected in different periods of the day no significant change in temperature was observed between sampling and stations. However, thermal stratification of the water column during the period lead to a significant reduction in dissolved oxygen in the hypolimnion, reaching 0.07 to $2.62 \mathrm{mg} \mathrm{L}^{-1}$ (Ex.: Station 5) (Fig. 3 and Supplementary Fig. 1). Thermal stratification was particularly evident in the first two campaigns when the reservoir volume decreased very little, less than

Tab. 1. Mean, maximum and minimum values for the variables monitored in surface waters of the Castanhão reservoir, NE Brazil, during the monitoring period.

\begin{tabular}{|c|c|c|c|c|c|c|c|}
\hline Variables & Statistics & $\begin{array}{l}\text { November } 2011 \\
\qquad(n=6)\end{array}$ & $\begin{array}{l}\text { March } 2012 \\
\quad(n=6)\end{array}$ & $\begin{array}{l}\text { August } 2012 \\
\qquad(\mathrm{n}=10)\end{array}$ & $\begin{array}{c}\text { January } 2013 \\
\qquad(\mathrm{n}=10)\end{array}$ & $\begin{array}{l}\text { August } 2013 \\
\qquad(\mathrm{n}=10)\end{array}$ & $\begin{array}{c}\text { May } 2014 \\
(n=10)\end{array}$ \\
\hline Temperature $\left({ }^{\circ} \mathrm{C}\right)$ & $\begin{array}{l}\text { Mean } \pm \text { SD } \\
\text { Min-Max }\end{array}$ & $\begin{array}{l}28.9 \pm 0.3^{\mathrm{a}} \\
28.7-29.3\end{array}$ & $\begin{array}{l}30.2 \pm 0.6^{\mathrm{b}} \\
29.5-31.0\end{array}$ & $\begin{array}{l}27.8 \pm 0.3^{c} \\
27.3-28.3\end{array}$ & $\begin{array}{l}28.8 \pm 0.3^{\mathrm{a}} \\
28.3-29.3\end{array}$ & $\begin{array}{l}29.1 \pm 0.5^{\mathrm{a}} \\
28.1-29.8\end{array}$ & $\begin{array}{l}30.4 \pm 1.0^{\mathrm{b}} \\
29.7-32.6\end{array}$ \\
\hline Secchi (m) & $\begin{array}{l}\text { Mean } \pm \text { SD } \\
\text { Min-Max }\end{array}$ & $\begin{array}{c}3.4 \pm 0.6^{\mathrm{ac}} \\
2.7-4.0\end{array}$ & $\begin{array}{c}2.3 \pm 0.4^{b} \\
1.7-2.9\end{array}$ & $\begin{array}{c}3.4 \pm 0.3^{\mathrm{c}} \\
3.0-3.8\end{array}$ & $\begin{array}{c}2.8 \pm 0.4^{\mathrm{ab}} \\
2.0-3.2\end{array}$ & $\begin{array}{c}2.5 \pm 0.4^{b} \\
2.0-3.2\end{array}$ & $\begin{array}{c}2.3 \pm 0.8^{\mathrm{b}} \\
1.0-3.0\end{array}$ \\
\hline Turbidity (NTU) & $\begin{array}{l}\text { Mean } \pm \text { SD } \\
\text { Min-Max }\end{array}$ & $\begin{array}{c}1.3 \pm 0.1^{\mathrm{ab}} \\
1.1-1.5\end{array}$ & $\begin{array}{c}1.1 \pm 0.1^{\mathrm{a}} \\
1.0-1.3\end{array}$ & $\begin{array}{c}1.3 \pm 0.2^{\mathrm{ab}} \\
1.1-1.6\end{array}$ & $\begin{array}{c}1.5 \pm 0.3^{\mathrm{ab}} \\
1.1-2.2\end{array}$ & $\begin{array}{c}1.5 \pm 0.6^{\mathrm{ab}} \\
1.1-2.9\end{array}$ & $\begin{array}{c}1.9 \pm 1.0^{\mathrm{b}} \\
1.2-4.2\end{array}$ \\
\hline Conductivity $\left(\mu \mathrm{S} \mathrm{cm}^{-1}\right)$ & $\begin{array}{l}\text { Mean } \pm \text { SD } \\
\text { Min-Max }\end{array}$ & $\begin{array}{c}295 \pm 2^{\mathrm{a}} \\
294-298\end{array}$ & $\begin{array}{l}313 \pm 4^{\mathrm{ab}} \\
308-317\end{array}$ & $\begin{array}{c}315 \pm 8^{\mathrm{b}} \\
307-328\end{array}$ & $\begin{array}{c}343 \pm 7^{c} \\
334-354\end{array}$ & $\begin{array}{c}347 \pm 9^{c} \\
340-372\end{array}$ & $\begin{array}{l}353 \pm 20^{c} \\
322-372\end{array}$ \\
\hline Dissolved oxygen ( $\mathrm{mg} \mathrm{L}^{-1}$ ) & $\begin{array}{l}\text { Mean } \pm \text { SD } \\
\text { Min-Max }\end{array}$ & $\begin{array}{c}7.0 \pm 0.1^{\mathrm{a}} \\
6.9-7.1\end{array}$ & $\begin{array}{c}6.6 \pm 0.2^{\mathrm{a}} \\
6.4-6.8\end{array}$ & $\begin{array}{c}7.0 \pm 0.3^{\mathrm{a}} \\
6.6-7.5\end{array}$ & $\begin{array}{c}6.8 \pm 0.7^{\mathrm{a}} \\
6.1-8.4\end{array}$ & $\begin{array}{c}6.6 \pm 0.4^{\mathrm{a}} \\
6.0-7.4\end{array}$ & $\begin{array}{l}7.7 \pm 1.8^{\mathrm{a}} \\
6.5-11.7\end{array}$ \\
\hline $\mathrm{pH}$ & $\begin{array}{l}\text { Mean } \pm \text { SD } \\
\text { Min-Max }\end{array}$ & $\begin{array}{c}8.1 \pm 0.1^{\mathrm{abc}} \\
8.0-8.2\end{array}$ & $\begin{array}{c}8.1 \pm 0.2^{\mathrm{abc}} \\
7.9-8.4\end{array}$ & $\begin{array}{c}7.7 \pm 0.3^{\mathrm{ab}} \\
7.1-8.0\end{array}$ & $\begin{array}{c}7.5 \pm 0.3^{\mathrm{a}} \\
7.2-8.1\end{array}$ & $\begin{array}{c}8.2 \pm 0.4^{\mathrm{bc}} \\
7.6-8.8\end{array}$ & $\begin{array}{c}8.7 \pm 0.7^{\mathrm{c}} \\
7.1-9.9\end{array}$ \\
\hline Chlorophyll $a\left(\mu \mathrm{g} \mathrm{L}^{-1}\right)$ & $\begin{array}{l}\text { Mean } \pm \text { SD } \\
\text { Min-Max }\end{array}$ & $\begin{array}{c}2.6 \pm 1.2^{\mathrm{a}} \\
1.3-4.0\end{array}$ & $\begin{array}{c}3.7 \pm 1.2^{\mathrm{ab}} \\
2.3-5.3\end{array}$ & $\begin{array}{c}4.0 \pm 1.2^{\mathrm{ab}} \\
2.1-6.1\end{array}$ & $\begin{array}{c}4.1 \pm 1.3^{\mathrm{ab}} \\
2.4-6.4\end{array}$ & $\begin{array}{c}5.2 \pm 2.5^{\mathrm{ab}} \\
2.6-9.8\end{array}$ & $\begin{array}{c}14.8 \pm 11.4^{\mathrm{b}} \\
2.7-37.9\end{array}$ \\
\hline Tot-P $\left(\mu \mathrm{g} \mathrm{L}^{-1}\right)$ & $\begin{array}{l}\text { Mean } \pm \text { SD } \\
\text { Min-Max }\end{array}$ & $\begin{array}{l}27.2 \pm 8.9^{\mathrm{ab}} \\
22.2-40.5\end{array}$ & $\begin{array}{l}17.2 \pm 7.1^{\mathrm{a}} \\
9.5-28.0\end{array}$ & $\begin{array}{l}22.3 \pm 2.6^{\mathrm{a}} \\
17.8-25.3\end{array}$ & $\begin{array}{c}30.1 \pm 10.7^{\mathrm{ab}} \\
15.8-48.5\end{array}$ & $\begin{array}{c}20.6 \pm 8.7^{\mathrm{a}} \\
7.6-33.7\end{array}$ & $\begin{array}{r}49.1 \pm 18.8^{\mathrm{b}} \\
23.6-77.2\end{array}$ \\
\hline Tot-N $\left(\mu \mathrm{g} \mathrm{L}{ }^{-1}\right)$ & $\begin{array}{l}\text { Mean } \pm \text { SD } \\
\text { Min-Max }\end{array}$ & $\begin{array}{c}510 \pm 133^{a} \\
349-643\end{array}$ & $\begin{array}{c}397 \pm 167^{\mathrm{a}} \\
216-611\end{array}$ & $\begin{array}{c}489 \pm 190^{\mathrm{a}} \\
185-798\end{array}$ & $\begin{array}{c}405 \pm 170^{\mathrm{a}} \\
170-714\end{array}$ & $\begin{array}{c}481 \pm 158^{\mathrm{a}} \\
210-713\end{array}$ & $\begin{array}{l}598 \pm 312^{\mathrm{a}} \\
99-1.210\end{array}$ \\
\hline
\end{tabular}

Different letters are significant different mean values (HSD Tukey test, with $P \leq 0.05$ ). 

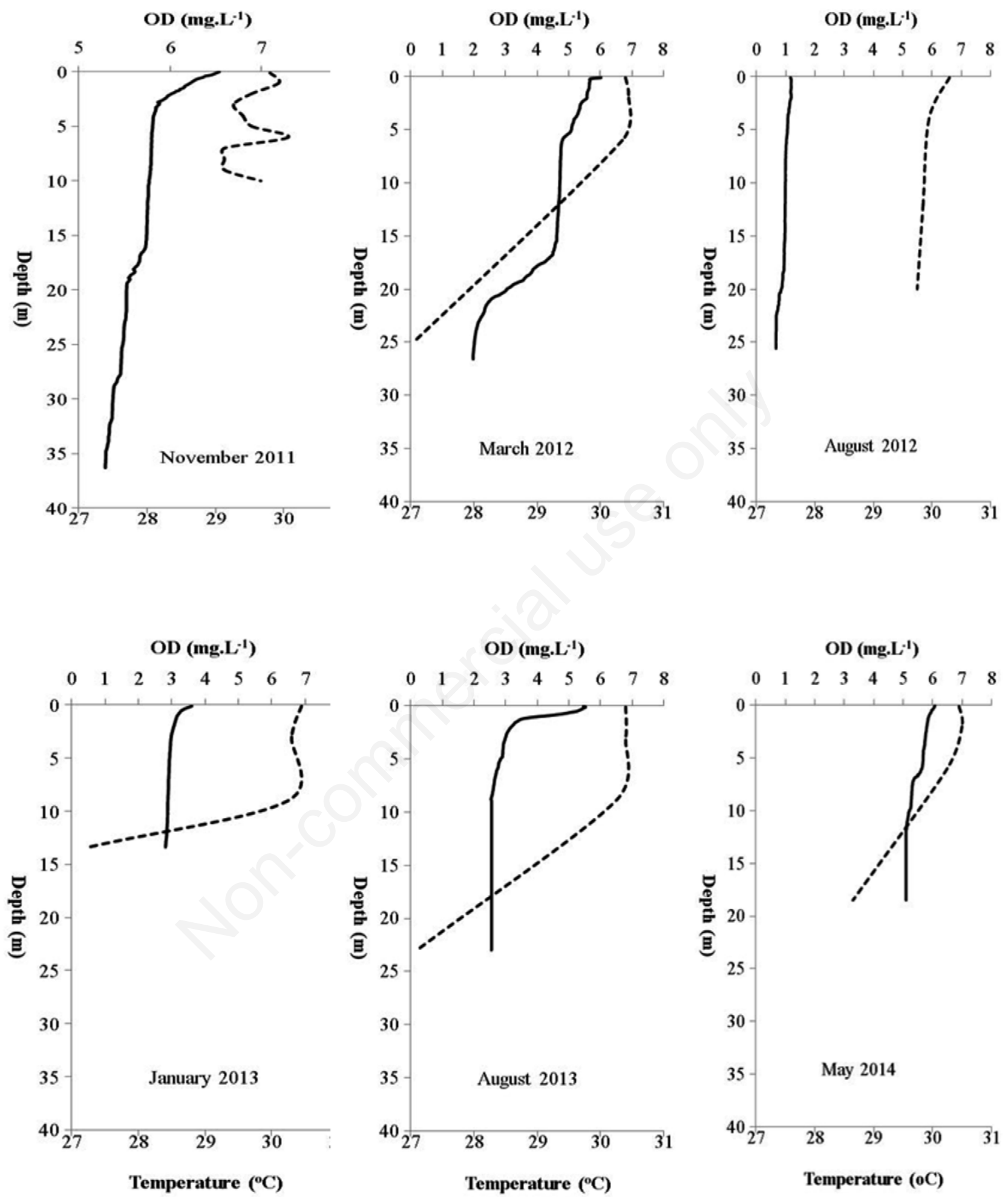

OD (mg.L $\left.\mathbf{~}^{-1}\right)$

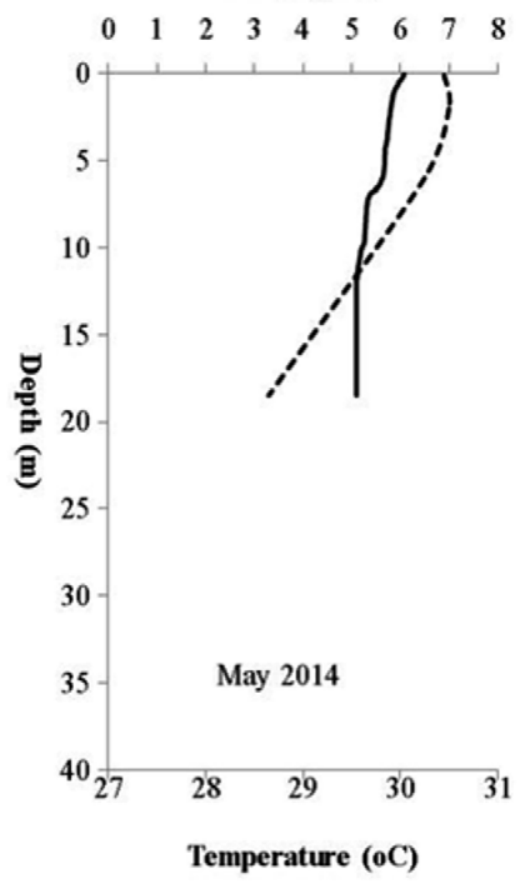

Fig. 3. Vertical profile of temperature and dissolved oxygen concentrations at station 5 during the monitoring period in the Castanhão reservoir, NE Brazil. 
$5 \%$. After that, thermal stratification disappeared, allowing wind induced mixing with the hypolimnion and a reduction in DO of the whole water column.

Average chlorophyll a concentrations differed significantly during the sampling period $(\mathrm{P} \leq 0.05)$ and increased progressively as the reservoir volume decreased (Tab. 1). Highest values occurred in May 2014 (12.4-37.9 $\mu \mathrm{g} \mathrm{L}^{-1}$ ) in stations 1 and 2. High turbidity also occurred in these period and stations. Water transparency decreased 4-fold during the studied period. Secchi disk depth ranged from $4.0 \mathrm{~m}$ (station 9) in November 2011 to $1.0 \mathrm{~m}$ (station 1) in May 2014. Turbidity values remained below 4.2 NTU, with the highest values recorded in August 2013 (station 1) and in May 2014 (stations 1, 2, 3 and 4). PCA analysis strongly suggests volume decrease as the major factor influencing turbidity and the chlorophyll- $a$ content. Average $\mathrm{pH}$ varied little throughout most of the sampling period from 7.5 to 8.2 , and were not significantly different. However, significantly higher $\mathrm{pH}$ values were recorded in May 2014 (8.7), when reservoir volume was lowest, following the increased photosynthetic activity as well as conductivity. Average electrical conductivity at $25^{\circ} \mathrm{C}$ increased progressively as the reservoir volume decreased from the lowest values of $295 \mu \mathrm{S} \mathrm{cm}^{-1}$ in the beginning of the study in November 2011 and reached its maximum average value in May 2014, of $353 \mu \mathrm{S} \mathrm{cm} \mathrm{cm}^{-1}$. The reservoir was well oxygenated at the surface (DO $>5 \mathrm{mg} \mathrm{L}^{-1}$ ) throughout the study and DO concentrations did not differ significantly throughout the monitoring period $(\mathrm{P}>0.05)$.

Total phosphorus concentration were significantly higher $(\mathrm{P}<0.05)\left(>45 \mu \mathrm{g} \mathrm{L}^{-1}\right)$ in May 2014, and lower and relatively similar (17 to $27 \mu \mathrm{g} \mathrm{L}^{-1}$ ) among the other sampling campaigns. Soluble reactive phosphorus concentrations (not shown in Tab. 1) were below the detection limit $\left(<1 \mu \mathrm{g} \mathrm{L}^{-1}\right)$ in most parts of the reservoir. Detectable concentrations occurred only in station 1 in January 2013 $\left(2.5 \pm 0.8 \mu \mathrm{g} \mathrm{L}^{-1}\right)$ and in station 5 in May $2014(25.8 \pm 1.8 \mu \mathrm{g}$ $\left.\mathrm{L}^{-1}\right)$. Nitrogen is the major nutrient component of the direct anthropogenic emissions to lake with a total annual emission of about 1,000 tons. Average total nitrogen concentrations did not differ significantly throughout the sampling period (397-598 $\left.\mu \mathrm{g} \mathrm{L}^{-1}\right)$. In most sampling stations and campaigns, nitrate, ammonia nitrogen and nitrite concentrations were below the detection limit. The highest detected concentrations were $83.0 \pm 3.5 \mu \mathrm{g} \mathrm{L}^{-1}$ (station 9 in March 2012) for nitrate and 327.2 $\pm 1.0 \mu \mathrm{g} \mathrm{L}^{-1}$ (station 5, in May 2014) for ammonia nitrogen. The availability of ammonia nitrogen in stations 5, 6, 7 and 8 in March 2012 might explain the algal blooms observed during that sampling campaign. Detectable nitrite concentrations $(2.5 \pm 0.1$ $\mu \mathrm{g} \mathrm{L}^{-1}$ ) occurred only in January 2013 and May 2014.

Similarities among stations during the monitoring period were evaluated using a multivariate cluster analysis considering all variables presented in Tab. 1. Two situation appeared when data from each campaigns were successively added to the analysis. During most of the monitoring period up to August 2013, two groups of stations were clearly recognized (Fig. 4a). A Group 1 including the deeper stations closer to the dam $(5,6,7,8$ and 9) with lower turbidity and $\mathrm{N}$ concentrations and a Group 2 including all shallower stations located along the fluvial axis of the reservoir (1, 2, 3, 4 and 10), differed by higher turbidity and $\mathrm{N}$ concentrations. When adding data from the last campaign, when reservoir level was at the lowest, the former Group 2 were subdivided, within two subgroups, (2A: stations 3, 4 and 10; 2B: stations 1 and 2); mostly differed by turbidity and Secchi disk depth (Fig. 4b). Group 1 included stations characterized by greater depths at the proximity to the dam. The area receives the largest effluents form fish farms and irrigated agriculture; and suggest an accumulation site for the nutrients drained from these activities, confirmed by the highest concentrations of $\mathrm{P}$ and $\mathrm{N}$ in stations of this group compared to Group 2, at least up to August 2013. In May 2014, Group 2B including stations 1 and 2, located at shallower depths and in regions further upstream of the dam, differed from the other by highest turbidity and lowest Sec-
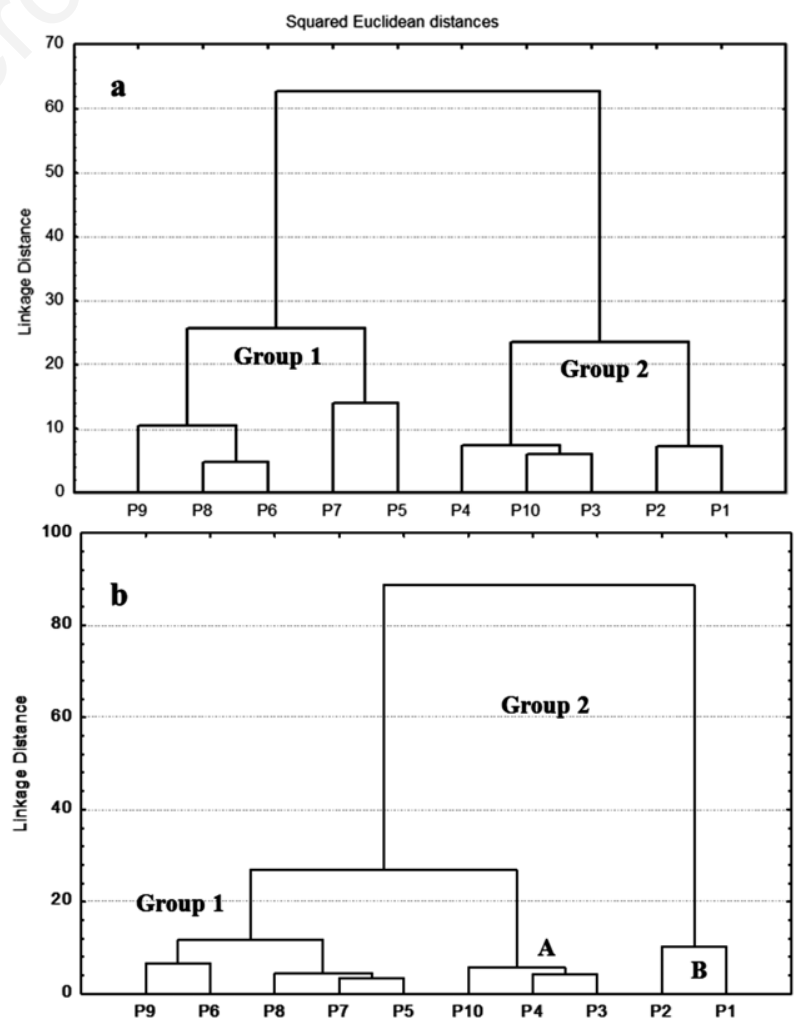

Fig. 4. Cluster analysis of the sampling stations in the Castanhão reservoir. Including all the monitoring period and variables shown in Tab. 1. (a) From November 2011 to August 2013. (b) May 2014. 
chi disk depth associated with the progressively shallower depths of the stations. In addition, Group 2B presented the highest chlorophyll $a$ concentrations, which caused supersaturation of dissolved oxygen to occur (Tab. 2).

A principal component analysis of the data throughout the sampling periods illustrates the temporal changes in water quality of the reservoir through time (Fig. 5). Factor 1 (mostly chlorophyll a and total phosphorus) explain bout $40 \%$ of the variation in hydrochemistry, followed by factor 2 (total nitrogen) explaining about $14 \%$ of the variability (Tab. 3). The PCA clearly shows the impact of volume on chlorophyll a, total phosphorus and total nitrogen concentrations through time, which will then affect the reservoir's trophic state index.

Fig. 6 shows the trophic state index variation in relation to the decreasing reservoir capacity. The trophic state index differed slightly between the spatial groups throughout the sampling period. The reservoir area encompassed by Group 1 remained oligotrophic from November 2011 to March 2012 and mesotrophic from August 2012 to May 2014 , mostly due to a continuous increase in chlorophyll a. Phosphorus only showed a significant increase in May 2014 also contributing to the change in trophic state. In the area encompassed by Group 2A and Group 2B, waters remained oligotrophic throughout most of the monitored period, but with Group 2A, turning eutrophic and Group 2B, turning supereutrophic in May 2014, when the reser- voir attained its minimum volume and a peak in chlorophyll $a$ and phosphorus concentrations occurred.

\section{DISCUSSION}

The decrease in reservoir volume and the consequent lack of water renewal by rainfall, strong evaporation and

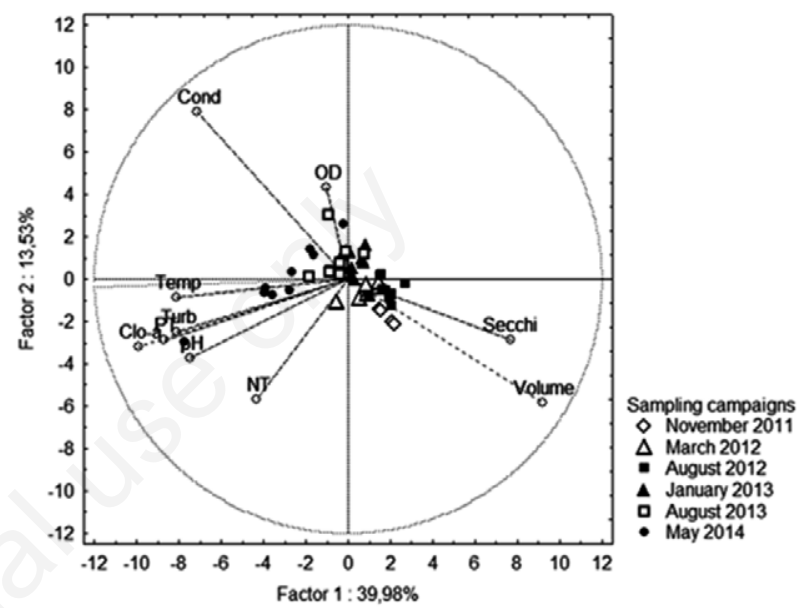

Fig. 5. Principal component analyses (PCA) of the Castanhão hydrochemistry during the study period.

Tab. 2. Mean, maximum and minimum values of the studied variables in surface water observed in the Castanhão reservoir in the different groups depicted by the cluster analysis in May 2014.

\begin{tabular}{|c|c|c|c|c|}
\hline Variables & Statistics & $\begin{array}{l}\text { Group } 1 \\
(n=29)\end{array}$ & $\begin{array}{l}\text { Group 2A } \\
\qquad(n=13)\end{array}$ & $\begin{array}{l}\text { Group 2B } \\
\qquad(\mathrm{n}=10)\end{array}$ \\
\hline Temperature $\left({ }^{\circ} \mathrm{C}\right)$ & $\begin{array}{l}\text { Mean } \pm \text { SD } \\
\text { Min-Max }\end{array}$ & $\begin{array}{l}28.9 \pm 1.0^{\mathrm{a}} \\
27.4-31.0\end{array}$ & $\begin{array}{l}28.6 \pm 0.7^{\mathrm{a}} \\
27.3-29.9\end{array}$ & $\begin{array}{l}29.6 \pm 1.7^{\mathrm{a}} \\
28.1-32.6\end{array}$ \\
\hline Secchi (m) & $\begin{array}{l}\text { Mean } \pm \text { SD } \\
\text { Min-Max }\end{array}$ & $\begin{array}{c}3.0 \pm 0.6^{\mathrm{a}} \\
1.7-4.0\end{array}$ & $\begin{array}{c}2.9 \pm 0.5^{\mathrm{ab}} \\
2.0-3.6\end{array}$ & $\begin{array}{c}2.2 \pm 0.8^{\mathrm{b}} \\
1.0-3.4\end{array}$ \\
\hline Turbidity (NTU) & $\begin{array}{l}\text { Mean } \pm \text { SD } \\
\text { Min-Max }\end{array}$ & $\begin{array}{c}1.2 \pm 0.1^{\mathrm{a}} \\
1.0-1.5\end{array}$ & $\begin{array}{c}1.5 \pm 0.3^{\mathrm{b}} \\
1.2-2.2\end{array}$ & $\begin{array}{c}2.2 \pm 1.0^{\mathrm{b}} \\
1.5-4.2\end{array}$ \\
\hline Conductivity $\left(\mu \mathrm{S} \mathrm{cm}^{-1}\right)$ & $\begin{array}{l}\text { Mean } \pm \text { SD } \\
\text { Min-Max }\end{array}$ & $\begin{array}{l}315 \pm 16^{\mathrm{a}} \\
294-344\end{array}$ & $\begin{array}{l}332 \pm 17^{\mathrm{a}} \\
307-354\end{array}$ & $\begin{array}{l}336 \pm 12^{a} \\
322-354\end{array}$ \\
\hline $\mathrm{DO}\left(\mathrm{mg} \mathrm{L}^{-1}\right)$ & $\begin{array}{l}\text { Mean } \pm \text { SD } \\
\text { Min-Max }\end{array}$ & $\begin{array}{c}6.9 \pm 0.5^{\mathrm{a}} \\
6.3-8.4\end{array}$ & $\begin{array}{c}6.8 \pm 0.3^{\mathrm{a}} \\
6.1-7.1\end{array}$ & $\begin{array}{l}7.8 \pm 2.0^{\mathrm{a}} \\
6.2-11.7\end{array}$ \\
\hline $\mathrm{pH}$ & $\begin{array}{l}\text { Mean } \pm \text { SD } \\
\text { Min-Max }\end{array}$ & $\begin{array}{c}7.9 \pm 0.3^{\mathrm{a}} \\
7.2-8.4\end{array}$ & $\begin{array}{c}7.6 \pm 0.3^{\mathrm{a}} \\
7.1-8.0\end{array}$ & $\begin{array}{c}8.4 \pm 0.8^{\mathrm{a}} \\
7.4-9.9\end{array}$ \\
\hline Chlorophyll $a\left(\mu \mathrm{g} \mathrm{L}^{-1}\right)$ & $\begin{array}{l}\text { Mean } \pm \text { SD } \\
\text { Min-Max }\end{array}$ & $\begin{array}{c}4.1 \pm 1.4^{\mathrm{a}} \\
1.3-6.4\end{array}$ & $\begin{array}{c}3.2 \pm 0.7^{\mathrm{a}} \\
2.1-4.5\end{array}$ & $\begin{array}{c}10.6 \pm 14.7^{\mathrm{a}} \\
2.1-37.9\end{array}$ \\
\hline Tot-P $\left(\mu \mathrm{g} \mathrm{L}^{-1}\right)$ & $\begin{array}{l}\text { Mean } \pm \text { SD } \\
\text { Min-Max }\end{array}$ & $\begin{array}{c}25.4 \pm 10.6^{\mathrm{a}} \\
9.5-48.5\end{array}$ & $\begin{array}{l}23.1 \pm 4.7^{\mathrm{a}} \\
12.0-30.0\end{array}$ & $\begin{array}{c}31.5 \pm 21.3^{\mathrm{a}} \\
7.6-77.2\end{array}$ \\
\hline Tot-N $\left(\mu \mathrm{g} \mathrm{L}^{-1}\right)$ & $\begin{array}{l}\text { Mean } \pm \text { SD } \\
\text { Min-Max }\end{array}$ & $\begin{array}{c}492.0 \pm 162.2^{\mathrm{a}} \\
264.3-797.9\end{array}$ & $\begin{array}{c}364.7 \pm 160.5^{\mathrm{a}} \\
169.8-706.0\end{array}$ & $\begin{array}{c}512.5 \pm 176.7^{\mathrm{a}} \\
259.3-746.0\end{array}$ \\
\hline
\end{tabular}

Different letters are significant different mean values $(P \leq 0.05)$. 
the permanent influence of anthropogenic activities' emissions, mostly from fish farming, irrigated agriculture and urban wastes, favored the concentration of salts, the accumulation of nutrients and increasing $\mathrm{pH}$. Previous studies in lakes and reservoirs in semiarid regions showed high electrical conductivity that typically exceed $300 \mu \mathrm{S}$ $\mathrm{cm}^{-1}$ and exhibit a negative correlation with water level (Bouvy et al., 1999; Eskinazi-Sant'Anna et al., 2007; Barbosa et al., 2012). In addition, wind forcing under decreasing volume produces rapid water mixing and

Tab. 3. Principal component analyses (PCA) of the Castanhão hydrochemistry. Underlined numbers are significant at $\mathrm{P}<0.05$ $(\mathrm{n}=52)$.

\begin{tabular}{lcc} 
Variable & Factor 1 & Factor 2 \\
Temperature & -0.674890 & -0.072759 \\
\hline Turbidity & -0.676510 & -0.206673 \\
\hline Conductivity & -0.595970 & $\underline{0.660054}$ \\
\hline Dissolved oxygen & -0.086678 & 0.361447 \\
\hline pH & -0.623495 & -0.309359 \\
\hline Secchi & 0.639051 & -0.236606 \\
\hline Chlorophyll a & $\underline{-0.825686}$ & -0.266973 \\
\hline Total phosphorus & $\underline{-0.724864}$ & -0.240770 \\
\hline Total nitrogen & -0.362774 & $\underline{-0.471254}$ \\
\hline Volume & $\underline{0.765747}$ & -0.485564 \\
\hline Expl. Var & 3.998125 & 1.353106 \\
\hline Prp. totl & $\underline{0.399813}$ & $\underline{0.135311}$ \\
\hline
\end{tabular}

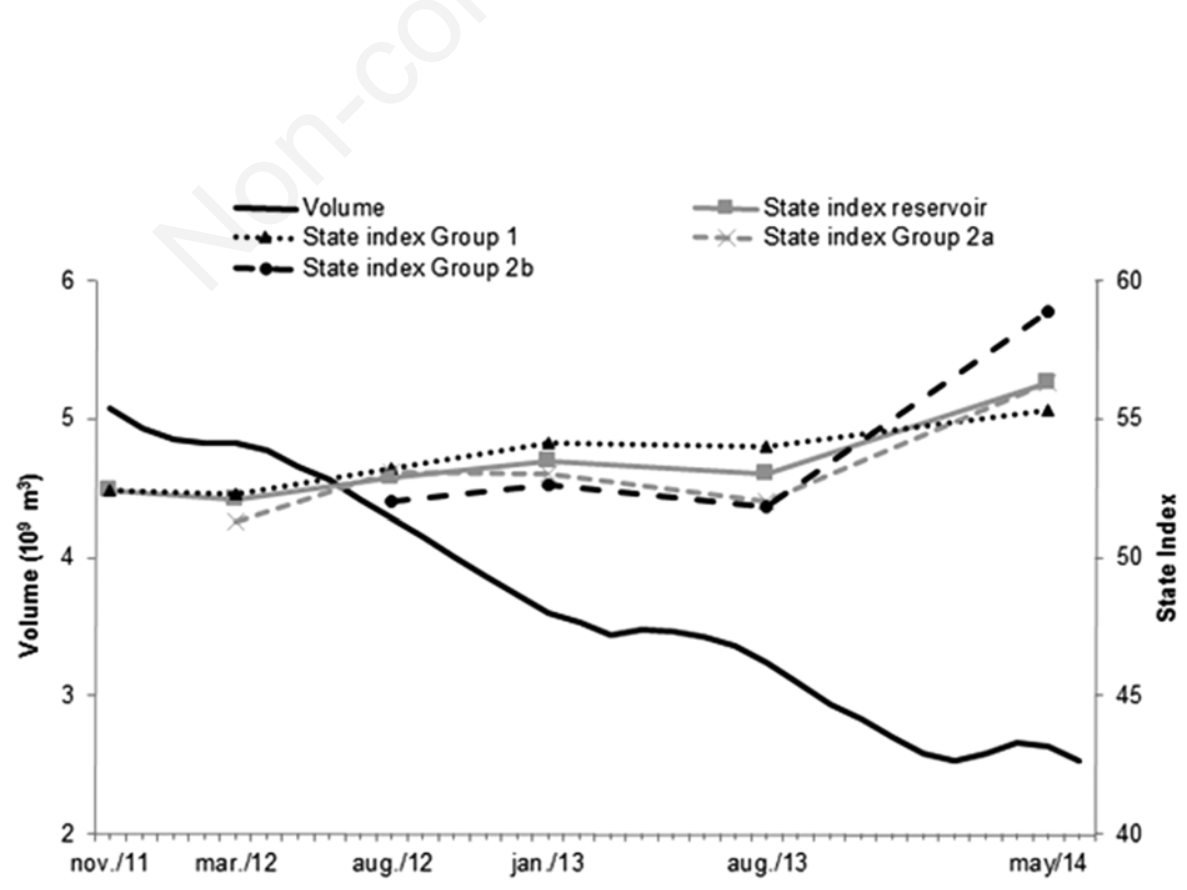

Fig. 6. Trophic state index and its relationship with reservoir capacity fluctuations in the Castanhão reservoir in NE Brazil, along the monitoring period. sediment resuspension, changing water column properties and bringing up accumulated nutrients from the hypolimnion (Freire et al., 2009).

At the Castanhão reservoir decreasing volume is associated with increasing electrical conductivity, total phosphorus, turbidity, $\mathrm{pH}$ and to a lesser extent with total nitrogen, strengthen the interaction between reservoir volume and water chemistry. Thermal stratification of the water column led to oxycline formation along with a significant reduction in dissolved oxygen in the hypolimnion, but not at the surface. The increased concentration of organic detritus at the bottom of the water column and the subsequent decomposition of this material consume large amounts of oxygen and induce anoxia, as exemplified by station 5 (but see also Supplementary Tab. 1).

Chlorophyll $a$ concentration is a good proxy of phytoplankton biomass and a valuable indicator of the trophic status of a water body. Salas and Martino (2001) used chlorophyll $a$ concentrations to classify the trophic statuses of tropical lakes and suggested concentrations of 5 to $10 \mu \mathrm{g} \mathrm{L}^{-1}$ as indicative of a mesotrophic state. Average chlorophyll $a$ concentrations in the Castanhão reservoir remained below $5 \mu \mathrm{g} \mathrm{L}^{-1}$ up to January 2013. Afterwards, concentrations in all stations exceeded $5 \mu \mathrm{g} \mathrm{L}^{-1}$, and exceeded $10 \mu \mathrm{g} \mathrm{L}^{-1}$, in May 2014 in stations 1, 2, 3, 4 e 9. Simultaneously, total phosphorus concentrations exceeded $35 \mu \mathrm{g} \mathrm{L}^{-1}$, within the range of values considered as the initial the values at which the deleterious environmental effects of eutrophication begin to appear (Dodds et al., 1998; Salas and Martino 2001).

The increasing nutrient concentrations observed after

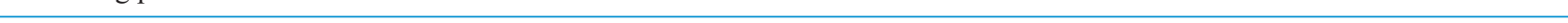


January 2013 might have resulted from the remobilization of accumulated nutrients in the hypolimnion and sediments consequent to the longer residence time of the reservoir. Previous observation on nutrient balance in the Castanhão reservoir showed a net retention of over $97 \%$ of the total fluvial input of $\mathrm{N}$ and $\mathrm{P}$ within the reservoir resulting in nutrient accumulation mostly in the hypolimnion (Molisani et al., 2013). With decreasing water depth, wind action can break the stability of the water column, thus favoring water column mixing processes and the resuspension of bottom material and the consequent increase in nutrient concentrations. These processes have been suggested to explain increasing nutrient concentrations in various reservoirs from the semiarid region during drought periods (Bouvy et al. 2003; Freire et al., 2009; Geraldes and George 2012).

Eventually, variations in the reservoir water level can result in changes in the physical and chemical structure of the system and consequently the dynamics of plankton communities, including zooplankton abundance (Geraldes and George, 2012), phytoplankton (Chalar, 2006), cyanobacteria blooms (Bouvy et al., 2003; Silva et al., 2013) and diversity (Costa et al., 2009). Naselli-Flores (2000) even suggested that water level fluctuations, influence phytoplankton composition more strongly than the nutrients levels. For example, a reduction in the reservoir volumes in Sicily during the spring because of the high demand from summer usage strongly affected the phytoplankton and nutrient dynamics, leading to eutrophication and the selection of cyanobacteria species that were harmful to human health (Naselli-Flores, 2003).

The trophic state index indicated a change in the trophic status of the Castanhão reservoir from oligotrophic to eutrophic during this extended drought period. In a short monitoring study between November 2006 and July 2007, Molisani et al. (2010) classified this reservoir as mesotrophic and detected anoxic events as well as the presence of cyanobacteria typical of mesotrophic/eutrophic environments, just after a two-year drought period. Chaves et al. (2013) also observed that the trophic state of a reservoir in the semiarid region relates to seasonal fluctuations in rainfall.

The observed deterioration of the TSI, however, was not evenly distributed in the entire reservoir. The three different groups identified and separated by their hydro chemical variables (Fig. 4) responded with different timing in developing eutrophic conditions. Group 1, including those deeper stations, receiving effluents from fish farming and irrigated agriculture, became mesotrophic and reached a eutrophic state earlier than the other groups. As water volume decreased further, Group 2A and 2B, characterized by much shallower water depth, became eutrophic. Further, when reservoir volume reached its minimum Group 2B, including the shallowest stations, became hypereutrophic. This suggest that a first process inducing changes in the trophic state was the concentration and accumulation of nutrients from anthropogenic activities, surrounding Group 1 region (Fig. 1) following the decrease in the reservoir volume. Afterwards, apart from continuing accumulation, and extra enrichment of nutrients was due to breaking thermal stratification, mixing of the water column (Groups 2A, 2B), and at least in the shallowest stations (Group 2B) sediment resuspension.

Molisani et al. (2015) reported, based on stable C and $\mathrm{N}$ distribution, current velocities and deposition rates of fecal pellets, that effluents from cage aquaculture (feed and feces) were not extensively reaching the water column and the bottom sediments of the cage area, on the contrary, effluents from farms are carried out to the deeper, central region of the reservoir. Hydrodynamic modeling of the reservoir (Molisani et al., 2015; Oliveira et al., 2015) showed surface wind-drive currents to move westwards from the center deeper part of the reservoir to shore, whereas bottom currents flush-out fish farm areas and incoming runoff eastwards to the deeper regions (Group 1 region), where stratification exists during high volume periods (e.g., in station 6 in November, 2011 - Supplementary Tab. 1), but is broken when the reservoir volume decreases. This contributes to the increase in nutrients in the hypolimnion of the reservoir. With the intense drought in recent years, this nutrient-rich hypolimnion waters mix with the entire column, increasing eutrophication, as showed by the TSI of the latter periods of the study.

Unfortunately, by comparing the emission of a single farm (67 t production) with the total $\mathrm{N}$ contribution from the watershed, Molisani et al. (2015) reached the conclusion that fish farming contributes relatively little to the total $\mathrm{N}$ inputs to the reservoir. When extrapolated to the entire fish production of the reservoir, however, this activity is the largest direct contributor of $\mathrm{N}$ and $\mathrm{P}$ to the reservoir. The hydrodynamics of the lake, cleanses the farm areas by exporting the majority of its effluents to deeper parts of the lake, where nutrients are accumulated under the thermocline establish when the reservoir is in its maximum volume, reaching over $54 \mathrm{~m}$ in depth in the central part. Under the intense drought verified during the study period, however, these accumulated nutrients are release to the water column following disruption of the thermocline due to shallower depths and triggering eutrophication.

The results obtained in this study raise concern on the sustainability of fish farming in semiarid reservoirs under a scenario of global climate change. The multiple use of reservoir waters in regions of hot and cold semiarid climate is presently constrained by global climate change (Jeppesen et al., 2015). Most global modeling showed these regions to be strongly affected by reduced precipitation and enhanced evaporation, as predicted for northeastern Brazil (Oyama and Nobre, 2003; Marengo et al., 2009). Actually, 
reduction in the annual rainfall has already been recorded for the region. Moncunill (2006) has estimated an average decrease of $5.6 \mathrm{~mm} . \mathrm{yr}^{-1}$ of rainfall since the 1960's over the Ceará State, whereas Godoy and Lacerda (2015) suggested that reduction of annual rainfall, in particular during the dry season, drastically reduced the Jaguaribe River flow over the middle Jaguaribe River Basin, where the Castanhão reservoir is located. Climate change is intensifying the symptoms of eutrophication in freshwaters, mostly affecting diffuse sources of nutrients to lakes and reservoirs (Jeppesen et al., 2015) increasing nutrient concentrations due to evaporation in reduced water volumes becomes an additional factor strengthening eutrophication. At the Castanhão reservoir, average decrease of rainfall will extend the duration of drought periods, such as the one covered by this study. This will result in volume decrease, breaking of the thermal stratification and triggering eutrophication. Falling reservoir levels apart from directly concentrating the nutrients already present in the water column, released by in-lake activities such as aquaculture, will expose sediments from margins and shallow areas receiving up-basin effluents from agriculture and husbandry and urban areas, to mineralization and increasing nutrient release to the lake.

\section{CONCLUSIONS}

The prolonged period of drought caused a dramatic decrease of the reservoir volume, which in turn induced changes in the physical and chemical structure of the system that resulted in eutrophication. The formation of spatially different compartments regarding the major physical and chemical parameters, however, suggests that the intensity of the eutrophication process in not uniformly distributed in the reservoir.

When normal rainfall periods keep elevated reservoir volumes, specific water current patterns wash out effluents from fish farms and irrigated agriculture transferring them to deeper layers, where nutrients accumulate in a relatively segregated hypolimnion. When the reservoir becomes shallower, breaking of the thermal stratification and sediment remobilization accelerates nutrient enrichment of the water column and triggers eutrophication.

The scenario of global climate change has to be taken into consideration to the decision-making processes aiming to ensure the sustainability of the multiple uses of the Castanhão reservoir and the preservation of high water quality for the noblest uses. Reducing rainfall and increasing frequency of extreme events, such as extended droughts and strong downpours, during the rainy seasons, of semiarid climate, will intensify the processes described for the Castanhão reservoir and will require re-dimensioning of fish aquaculture and irrigated agriculture, as well as better treatment of urban wastes.

\section{ACKNOWLEDGMENTS}

We thank the National Council for Scientific and Technological Development (CNPq-Brazil Proc. No. 573.601/2008-9) and the Ceará Foundation for Scientific and Technological Development (FUNCAP, Proc. Nos. $561.282 / 2010$ and $120.100 / 2011$ ) for financial support and grants to the authors.

\section{REFERENCES}

Avelino IIF, 2015. [Avaliação ambiental do Reservatório Castanhão (CE) utilizando o método DPSIR].[Thesis in Portuguese]. Universidade Federal do Ceará, Fortaleza.

Barbosa JEL, Medeiros ESF, Brasil J, Cordeiro RS, Crispim MCB, Silva GHG, 2012. Aquatic Systems in Semi-arid Brazil: limnology and management. Acta Limnol. Brasil. 24:103-118.

Bendschneider K, Robinson RJ, 1952. A new spectrophotometric method for the determination of nitrite in seawater. J. Mar. Res. 11:87-96.

Bezerra LAV, Paulino WD, Garcez DS, Becker H, SánchezBotero JI, 2014. Características limnológicas em um reservatório do semiárido brasileiro com cultivo intensivo de Orechromis niloticus (Linnaeus, 1758). Acta Limnol. Brasil. 26:47-59.

Bouvy M, Arfi R, Oliveira S, Marinho M, Beker B, 1999. Dynamics of a toxic cyanobacterial bloom (Cylindrospermopsis raciborskii) in a shallow reservoir in the semi-arid region of Northeast Brazil. Aquat. Microb. Ecol. 20:285-297.

Bouvy M, Nascimento SM, Molica RJR, Ferreira A, Huszar V, Azevedo SMFO, 2003. Limnological features in Tapacurá reservoir (northeast Brazil) during a severe drought. Hydrobiol. 493:115-130.

Braga GG, Becker V, Oliveira JNP, Mendonça Junior JR, Bezerra AFM, Torres LM, Galvão AMF, Mattos A, 2015. Influence of extended drought on water quality in tropical reservoirs in a semiarid region. Acta Limnol. Brasil. 27:15-23.

Chalar G, 2006. [Dinámica de la eutrofización a diferentes escalas temporales: embalse Salto Grande (Argentina-Uruguay)], p. 87-101. In: J.G. Tundisi, T. Matsumura-Tundisi and C.S. Galli (eds.), [Causas, consequências e tecnologias de gerenciamento e controle].[Book in Portuguese]. Instituto Internacional de Ecologia, São Paulo.

Chaves FIB, Lima PF, Leitão RC, Paulino WD, Santaella ST, 2013. Influence of rainfall on the trophic status of a Brazilian semiarid reservoir. Acta Scientiarum 35:505-511.

COGERH (Companhia de Gestão dos Recursos Hídricos), 2011. [Inventario Ambiental Açude Castanhão].[Book in Portuguese]. Geosolos Consultoria, Projetos e Serviços Ltda, Fortaleza: $142 \mathrm{pp}$.

Costa IAS, Cunha SRS, Panosso RF, Araújo MF, Melo JLS, Eskinazi-Sant'anna EM, 2009. [Dinâmica de cianobactérias em reservatórios eutróficos do semiárido do Rio Grande do Norte].[Article in Portuguese]. Oecol. Brasil. 13:382-401.

Cunha DGF, Calijuri MC, Lamparelli MC, 2013. A trophic state index for tropical/subtropical reservoirs $\left(\mathrm{TSI}_{\mathrm{tsr}}\right)$. Ecol. Engin. 60:126-134.

Dawadi S, Ahmad S, 2013. Evaluating the impact of demandside management on water resources under changing climatic conditions and increasing population. J. Environ. Manag.114:261-275. 
DNOCS (Departamento Nacional de Obras Contra as Secas), 2014. [Açude Castanhão].[In Portuguese]. Accessed: 10 June 2014. Available from: http://www.dnocs.gov.br

Dodds WK, Jones JR, Welch EB, 1998. Suggested classification of stream trophic state, distributions of temperate of stream trophic state: chlorophyll, total nitrogen, and phosphorus. Wat. Res. 32:1455-1462.

Eskinazi-Sant'anna EM, Menezes R, Costa IS, Panosso RF, Araújo MF, Attayde JL, 2007. [Composição da comunidade zooplanctônica em reservatórios eutróficos do semiárido do Rio Grande do Norte].[Article in Portuguese]. Oecol. Brasil. 11:410-421.

Freire RHF, Calijuri MC, Santaella ST, 2009. Longitudinal patterns and variations in water quality in a reservoir in the semiarid region of NE Brazil: responses to hydrological and climatic changes. Acta Limnol. Brasil. 21:251-262.

FUNCEME (Fundação Cearense de Meteorologia e Recursos Hídricos), 2014. [Chuvas: Séries Históricas].[In Portuguese]. Accessed in: October 2014. Available from: http://www.funceme.br/index.php/areas/tempo /downloadde-series-historicas

Geraldes AM, George C, 2012. Limnological variations of a deep reservoir in periods with distinct rainfall patters. Acta Limnol. Brasil. 24:417-426.

Godoy MDP, Lacerda LD, 2014. River-island response to landuse change within the Jaguaribe River, Brazil. J. Coast. Res. 30:399-410.

IBGE (Instituto Brasileiro de Geografia e Estatística), 2010. [Censo 2010].[In Portuguese]. Assessed in: June 2015. Available from: http:/www.censo2010.ibge.gov.br/pt/

IPECE (Instituto de Pesquisa e Estatística Econômica do Ceará), 2011. Assessed in June, 2015. Available from http://www2. ipece.ce.gov.br/publicacoes/ceara_em_numeros/2011/infra/ index.htm

ISO, 1992. Water quality measurement of biochemical parameters spectrophotometric determination of chlorophyll-a concentration. ISO Norm 10260. International Organization for Standardization, Geneva.

Jeppesen E, Brucet S, Naselli-Flores L, Papastergiadou E, Stefanidis K, Noges T, Attayde JL, Zohary T, Coppens J, Bucak T, Menezes RF, Freitas FRS, Kernan M, Søndergaard M, Beklioğlu M, 2015. Ecological impacts of global warming and water abstraction on lakes and reservoirs due to changes in water level and related changes in salinity. Hydrobiologia 750:201-227.

Koroleff F, 1970. Revised version of direct determination ammonia of natural waters as indophenol blue. Information on techniques and methods for sea water analysis. ICES Interlab. Rep. 3:19-22.

Lacerda LD, Molisani MM, Sena D, Maia LP, 2008. Estimating the importance of natural and anthropogenic sources on $\mathrm{N}$ and $\mathrm{P}$ emission to estuaries along the Ceará state coast NE Brazil. Environ. Monit. Assess. 141:149-164.

Lopes FB, Andrade EM, Meireles ACM, Becker H, Batista AA, 2014. Assessment of the water quality in a large reservoir in semiarid region of Brazil. R. Bras. Eng. Agríc. Ambiental 18:437-445.

Marengo JA, Jones R, Alvesa MLM, Valverdea MC, 2009. Future change of temperature and precipitation extremes in South America as derived from the PRECIS regional climate modeling system. Inter. J. Climatol. 29: 2241-2255.

Molisani MM, Barroso HS, Becker H, Moreira MOP, Hijo CAG, Monte TM, Vasconcellos GH, 2010. Trophic state, phytoplankton assemblages and limnological diagnosis of the Castanhão Reservoir, CE, Brazil. Acta Limnol. Brasil. 22:1-12.
Molisani MM, Becker H, Barroso HS, Hijo CAG, Monte TM, Vasconcellos GH, Lacerda LD, 2013. The influence of Castanhão reservoir on nutriente and suspended matter transport during rainy season in the ephemeral Jaguaribe River (CE, Brazil). Brazil. J. Biol. 73:115-123.

Molisani MM, Monte TM, Vasconcellos GH, Barroso, HS, Moreira MOP, Becker H, Rezende CE, Franco MAL, Farias EGG, Camargo PB, 2015. Relative effects of nutrient emission from intensive cage aquaculture on the semiarid reservoir water quality. Environ. Monit. Assess. 187:707-721.

Moncunill DF, 2006. The rainfall trend over Ceará and its implications, p. 315-323. Proc. $8^{\text {th }}$ Int. Conf. Southern Hemisphere Meteorology and Oceanography, Foz do Iguaçu.

Moss B, Kosten S, Meerhoff M, Battarbee RW, Jeppesen E, Mazzeo N, Havens K, Lacerot G, Liu Z, De Meester L, Paerl H, Scheffer M, 2011. Allied attack: climate change and eutrophication. Inland Waters 1:101-105.

Murphy J, Riley JP, 1962. A modified single solution method for the determination of phosphate in natural waters. Anal. Chim. Acta 27:31-36.

Naselli-Flores L, 2000. Phytoplankton assemblages in twentyone Sicilian reservoirs: relationship between species composition and environmental factors. Hydrobiologia 424:1-11.

Naselli-Flores L, 2003. Man-made lakes in Mediterranean semiarid climate: the strange case of Dr. Deep Lake and Mr. Shallow Lake. Hydrobiologia 506-509:13-21.

Oliveira KF, Lacerda LD, Peres TF, Bezerra MF, Dias FJS, 2015. Emission factor and balance of mercury in fish farms in an artificial reservoir in NE-Brazil. Environ. Sci. Pollut. Res. 22:18278-18287.

Oyama MD, Nobre CA, 2003. A new climate-vegetation equilibrium state for tropical South America. Geophys. Res. Lett. 30:2199-2203.

Paula Filho FJ, Marins RV, Lacerda LD, 2015. Natural and anthropogenic emissions of $\mathrm{N}$ and $\mathrm{P}$ to the Parnaíba River Delta in NE Brazil. Estuar. Coast. Shelf Sci. 166:34-44.

PBMC (Painel Brasileiro de Mudanças Climáticas), 2013. [Base científica das mudanças climáticas. Contribuição do Grupo de Trabalho 1ao Primeiro de Avaliação Nacional do Painel Brasileiro de Mudanças Climáticas. Sumário Executivo do GT2].[in Portuguese]. Painel Brasileiro de Mudanças Climáticas, Rio de Janeiro, Brasil.

Salas HJ, Martino P, 2001. Metodologías simplificadas para La evaluación de eutroficacion em lagos cálidos tropicales. Organización Panamericana de La Salud (OPS) - División de Salud y Ambiente. Centro Panamericano de Ingenieria Sanitaria y Ciências Del Ambiente (CEPIS).

Santos JCN, Andrade EM, Araújo Neto JR, Meireles AM, Palácio HAQ, 2014. Land use and trophic state dynamics in a tropical semi-arid reservoir. Rev. Ciênc. Agr. 45:35-44.

Silva LP, Santos JA Costa BGB, Bezerra MB, Silva ATF, Marins RV, 2013. Caracterização da comunidade fitoplanctônica no açude padre Cícero (Castanhão), CE. An. XIV Congr. Bras. Limnol. Associação Brasileira de Limnologia, Bonito, Mato Grosso do Sul, p:123.

Umaña G, 2014. Ten years of limnological monitoring of a modified natural lake in the tropics: Cote Lake, Costa Rica. Rev. Biol. Trop. 62:567-578.

Valderrama JC, 1981. The simultaneous analysis of total nitrogen and total phosphorus in natural waters. Mar Chem. 10:109-122.

World Commission on Dams, 2000. Dams and development: a new framework for decision-making. Earthscam Publications, London: 404 pp. 